\title{
Role of Higher Education in Creation of Knowledge Economy in Punjab, Pakistan
}

\section{Papel de la educación superior en la creación de la economía del conocimiento en Punjab, Pakistán}

Received: December 2, 2020

\begin{abstract}
Knowledge is working as an engine in achieving sustainable economic development goals for societies who are shifting from labor intensive economy to knowledge based economy like Pakistan. Education works like a backbone in knowledge based economies. Hence, the current research is planned to find out that is the educational institutions of Pakistan are contribution in production of new knowledge or not. Survey was the technique used by researcher for collection of information. Tool for gathering data was questionnaire and sample was selected from six public and private universities of Punjab Pakistan by applying simple random technique while the sample size was comprised of 606 respondents. Both descriptive and inferential statistical techniques were considered to analyze the data. Association found between the efforts made by higher educational institutions by providing access to knowledge, rich infrastructure, funds, incentives, research and development, human capital development, collaboration with industry and creation of knowledge economy.
\end{abstract}

Keywords: Knowledge economy, educational institutions, Scientific and Technological knowledge, Rich Infrastructure, Funds and Incentives, Research and Development, Human Capital Development, Collaboration with Industry.
Accepted: January 15, 2021

\author{
Written by: \\ Dr. Sajida Parveen ${ }^{8}$ \\ Dr. Babak Mahmood ${ }^{9}$ \\ Saira Siddiqui ${ }^{10}$ \\ Dr. Ayesha Ch. ${ }^{11}$ \\ Dr. Mudassar Mushtaq ${ }^{12}$
}

\section{Resumen}

El conocimiento funciona como un motor para lograr los objetivos de desarrollo económico sostenible para las sociedades que están pasando de una economía intensiva en mano de obra a una economía basada en el conocimiento como Pakistán. La educación funciona como la columna vertebral de las economías basadas en el conocimiento. Por lo tanto, la investigación actual está planeada para descubrir si las instituciones educativas de Pakistán contribuyen o no a la producción de nuevos conocimientos. La encuesta fue la técnica utilizada por el investigador para la recolección de información. La herramienta para recopilar datos fue un cuestionario y se seleccionó una muestra de seis universidades públicas y privadas de Punjab Pakistán aplicando una técnica aleatoria simple, mientras que el tamaño de la muestra estaba compuesto por 606 encuestados. Se consideraron técnicas estadísticas tanto descriptivas como inferenciales para analizar los datos. Asociación encontrada entre los esfuerzos realizados por las instituciones de educación superior al brindar acceso al conocimiento, rica infraestructura, fondos, incentivos, investigación y desarrollo, desarrollo del capital humano, colaboración con la industria y creación de la economía del conocimiento.

Palabras clave: economía del conocimiento, instituciones educativas, conocimiento científico y tecnológico, infraestructura rica, fondos $\mathrm{e}$ incentivos, investigación y desarrollo, desarrollo del capital humano, colaboración con la industria.

\footnotetext{
${ }^{8}$ Correspondent Author \& Lecturer Department of Sociology Govt. College Women University, Faisalabad.

${ }^{9}$ Associate Prof. Department of Sociology Govt. College University, Faisalabad.

${ }^{10}$ Assistant Prof. Department of Sociology Govt. College University, Faisalabad

11 Assistant Prof. Department of Sociology Govt. College University, Faisalabad.

${ }^{12}$ Lecturer Riphah International College, Faisalabad.
} 


\section{Introduction}

The nations are achieving their developmental goals by using knowledge as tool. In economic development of countries, knowledge plays a crucial role (Kefela, 2010). Countries need more graduates every year. Although, great expansion can be observed in numbers of graduates completed their degrees which leads to higher poverty rate in countries. To deal with such issues, an overview is required to examine that the education is being provided to the graduates is capable to meet the challenges of new economy or not. If countries do not pay attention to provide skills which are necessary for knowledge based economy they cannot perform well in the competitive global economy. Government has to finance educational institutions to make them favorable to learn new skills so the students can perform well in creativity and innovation for economic development of society (Levy \& Hopkins, 2010).

The future of any country now depends on development of knowledge society and knowledge economy. For development of these two sectors educational inputs are vital. New ideologies are required to make educational institutions conducive for generation of new knowledge. For doing so educational institutions have to pay attention on their individual actors (Forstorp \& Mellström, 2013).

Keeping in view the neoliberal reforms Pakistan is reconstructing its higher education system. Different policies are under consideration to define the role of varsities. For ensuring the quality and quantity, privatization and self financing are two measures which are becoming significant for educational system in country. But, they are short term approaches, some long term policy making is needed to develop the country socially and economically (Tarar, 2006).

It is emphasized that this is time for Pakistan to jump from labor intensive economy to Knowledge based economy. This economy is not based on material and labor inputs but on Knowledge and this transition requires rethinking and redesigning in fields of life especially in Education (Amjad, 2006).

The above mentioned literate highlights the importance of knowledge economy and the role of education as driving force of new economy. Thus, the current research is an effort to know that how higher educational institutions of Pakistan are struggling to generate new knowledge and is there any association between the efforts made by the educational intuitions and creation of knowledge economy.

\section{Review of Literature}

By sharing knowledge between universities and industry, a society can enhance innovation. Different studies were conducted to find the effects of collaboration of university and industry and it is suggested that more investigation is need to understand the link between both (Mushtaq, Parveen, Hussain, \& Iqbal, 2020)

Despite of this fact, it is evident that knowledge sharing between both university and industry produce new knowledge for the economic development of society. This collaboration enhances the chances of growth especially for developing countries those have limited resources (Ankrah \& Omar, 2015).

Scientific knowledge is maintained by the research activities because it is important for both society and educational institutions. The scientific knowledge has a direct impact on national and international growth of a country and teachers and students are the drivers of scientific knowledge. Academic research contributes to produce scientific knowledge and the future of any society can be predict on the basis of ongoing research projects (Ioana, Anda, Ioan \& Bianca, 2015).

Sustainable development and growth are highly attached with production of knowledge assets. Organizations now can realize that Knowledge management system is vital and different knowledge incentive programs are being developed for knowledge sharing and leaning. Results presentenced that the infrastructure of knowledge incentive program influence the knowledge sharing and leaning activities in the organization (Mathew \& Rodrigues, 2015).

Political and economical characteristics have significant importance in shaping the educational system of any country for coming decade. The aim of the countries is to develop most suitable educational system that can attract the attention of international students (Mushtaq, 2020). Moreover, it is concluded that to develop the quality of educational institutions research and teaching must be improved and for improvement international collaboration is essential for countries. It is analyzed that by 2020 an obvious change can be seen in theeducational system of 
East for generating new knowledge (British Council, 2012).

Universities are trying to promote research activities in campuses by funding to those who perform well in developing new knowledge. Research and innovation policies are revised by evaluating the educational system. Distribution of funding by universities in research activities increase the innovative environment and contributes to the growth of economy of the country (Hicks, 2012).

Up gradation in skills is essential for societies as new knowledge based economy depends on modern technologies. Technological changes demand alteration in existing educational system. Since, technologically advanced people are crucial for developing society economically (Kefela, 2010).

The long term economic growth of society can be highlighted through the role played by knowledge in its economy. Knowledge serves as an engine in new economy and investment in communication and information technologies, innovation and education is important to create to knowledge. Later, it will lead to develop a conducive environment for economic production. Different policies are understudy to help the societies to move manufacturing industries to idea based industries (Chen \& Dahlman, 2005).

The triangular relation between research, innovation and education is highlighted by European Union for developing countries economically by creating new knowledge. European Union put a strong emphasize on the key role of education in doing reach for innovation. The union launched a program to achieve their economic goals in next ten years and these three components were key factors for growth of their economy (Soriano \& Mulatero, 2010)

The UK government, OECD, and World Bank used critical discourse analysis to study the key policies for developing the educational sector for creating knowledge economy. Developing and developed countries can get help from polices of World Bank and OECD for redesigning educational sector. Market requirement, personalized learning and human capital formation are the key factors to keep in mind while setting the educational system of any country for producing knowledge economy as suggested by UK government, OECD, World Bank (Robertson, 2005).
The most important actor of new economy is an individual; in labor based economy machines were more important than the man. The new economy revolves around the knowledge and skills of an individual. If an organization wants to increase its profit it has to invest in developing its human capital because competitive advancement in business requires development of employee. By developing the talent of individual organizations can maximize their profit and can contribute to the economic growth of country (McGregor, Tweed \& Pech, 2004).

The literature enables us that countries are redesigning their educational system for making it suitable for production of knowledge economy. Moreover, the most significant components of generation of new knowledge are scientific and technological knowledge, infrastructure, funds incentives, research and development, human capital development and collaboration with industry. Therefore, in proceeding portion it can be analyzed that the educational system of Pakistan is trying to create knowledge by using these components or not.

\section{Methodology}

Survey, the most popular technique of social sciences, was preferred for interviewing the respondents whereas the interview schedule was used by the researcher for measuring the attitudes of people. The purpose of using the interview schedule was to elaborate the context of research to the respondents in a face to face interacting situation. The population of the study was the teachers, administrators, and students of six selected universities (three public and three private) of Punjab, Pakistan. 606 respondents were selected with the help of simple random technique. Sampling was done in a very careful manner because the information gathered by these respondents was used for generalization. 50 interviews were done for pre testing and some important changes were made after that. SPSS was the software used for analysis and both descriptive and inferential statistics methods were applied to interpret the data. Descriptive analysis was carried out with the help of percentage, measures of central tendency, and measures of variance) and inferential interpretation was done with the help of chisquare test, gamma statistics, reliability test through, Cronbach's alpha, the pearson correlation, multiple Linear regression. 


\section{AMAZOND周 \\ Iึvestiำ}

Results and Discussion
Hypothesis 1: There is association between access to Knowledge provided by educational institutions and creation of knowledge economy.

Table 1.

Association between access to knowledge and creation of knowledge economy.

\begin{tabular}{lllllll}
\hline \multirow{2}{*}{$\begin{array}{l}\text { Access to } \\
\text { Knowledge }\end{array}$} & \multicolumn{2}{l}{ Creation of Knowledge economy } & neither \\
\cline { 2 - 5 } strongly agree & agree & $\begin{array}{l}\text { agree nor } \\
\text { disagree }\end{array}$ & disagree & $\begin{array}{l}\text { strongly } \\
\text { disagree }\end{array}$ & Total \\
Strongly agree & 4 & 10 & 5 & 9 & 5 & 33 \\
& $12.1 \%$ & $30.3 \%$ & $15.2 \%$ & $27.3 \%$ & $15.2 \%$ & $100.0 \%$ \\
Agree & 12 & 52 & 74 & 57 & 3 & 198 \\
Neither agree & 20 & $26.3 \%$ & $37.4 \%$ & $28.8 \%$ & $1.5 \%$ & $100.0 \%$ \\
nor disagree & $9.4 \%$ & 50 & 66 & 63 & 13 & 212 \\
& 10 & $23.6 \%$ & $31.1 \%$ & $29.7 \%$ & $6.1 \%$ & $100.0 \%$ \\
Disagree & $8.3 \%$ & 27 & 38 & 41 & 5 & 121 \\
Strongly & 3 & $22.3 \%$ & $31.4 \%$ & $33.9 \%$ & $4.1 \%$ & $100.0 \%$ \\
disagree & $7.1 \%$ & 5 & 15 & 17 & 2 & 42 \\
Total & 49 & $11.9 \%$ & $35.7 \%$ & $40.5 \%$ & $4.8 \%$ & $100.0 \%$ \\
\hline
\end{tabular}

Tests

\begin{tabular}{llll}
\hline & Value & Df & Asymp. Sig. (2-sided) \\
\hline Pearson Chi-Square & $25.964^{\mathrm{a}}$ & 16 & .055 \\
Likelihood Ratio & 25.440 & 16 & .062 \\
Linear-by-Linear Association & 1.902 & 1 & .168 \\
Gamma & .069 & & .141 \\
\hline
\end{tabular}

Table 1 tells us about the relationship between access to knowledge and creation of knowledge economy. Chi-square value $\left(\chi^{2}=25.964 a\right)$ a highly significant $(\mathrm{p}=.055)$ which depicts association among access to knowledge and creation of knowledge economy. Likelihood Ratio (25.440) and Linear-by-Linear Association

(1.902) also showing a highly significant association between the variables. Gamma statistic depicts a significant and positive relation among the variables. Higher the access to knowledge is provided by the educational institutions higher will be the creation of knowledge economy as it can be evident by above mentioned responses. So, the hypothesis "There is association between access to Knowledge provided by educational institutions and creation of knowledge economy" is accepted. As recommended by Conceição \& Heitor, (1999) that some rethinking is needed to enhance the role of educational institutions to preserve knowledge.

Hypothesis 2: There is association between rich infrastructure of educational institutions and creation of knowledge economy. 
Table 2.

Association between rich infrastructure of educational institutions and creation of knowledge economy.

\begin{tabular}{lllllll}
\hline \multirow{2}{*}{$\begin{array}{l}\text { Infrastructure } \\
\text { Of educational } \\
\text { institutions }\end{array}$} & \multicolumn{2}{l}{ Creation of Knowledge economy } & neither \\
\cline { 2 - 4 } & $\begin{array}{l}\text { strongly } \\
\text { agree }\end{array}$ & Agree & $\begin{array}{l}\text { agree nor } \\
\text { disagree }\end{array}$ & disagree & $\begin{array}{l}\text { strongly } \\
\text { disagree }\end{array}$ & Total \\
Strongly agree & 13 & 6 & 0 & 0 & 0 & 19 \\
& $68.4 \%$ & $31.6 \%$ & $0.0 \%$ & $0.0 \%$ & $0.0 \%$ & $100.0 \%$ \\
Agree & 36 & 81 & 25 & 0 & 0 & 142 \\
Neither agree & $25.4 \%$ & $57.0 \%$ & $17.6 \%$ & $0.0 \%$ & $0.0 \%$ & $100.0 \%$ \\
nor disagree & 0 & 51 & 108 & 24 & 0 & 183 \\
& $0.0 \%$ & $27.9 \%$ & $59.0 \%$ & $13.1 \%$ & $0.0 \%$ & $100.0 \%$ \\
Disagree & $0.0 \%$ & 6 & 61 & 115 & 16 & 198 \\
Strongly & 0 & $3.0 \%$ & $30.8 \%$ & $58.1 \%$ & $8.1 \%$ & $100.0 \%$ \\
disagree & $0.0 \%$ & $0.0 \%$ & $6.3 \%$ & $78.0 \%$ & $18.8 \%$ & $100.0 \%$ \\
Total & 49 & 144 & 198 & 187 & 28 & 606 \\
\hline
\end{tabular}

Tests

\begin{tabular}{llll}
\hline & Value & Df & Asymp. Sig. (2-sided) \\
\hline Pearson Chi-Square & $566.697^{\mathrm{a}}$ & 16 & .000 \\
Likelihood Ratio & 592.165 & 16 & .000 \\
Linear-by-Linear Association & 374.305 & 1 & .000 \\
Gamma & .902 & & .000 \\
\hline
\end{tabular}

* = Significant

Table 2 explains the relationship between rich infrastructure of and production of knowledge. Chi-square value $(\chi 2=566.697 \mathrm{a})$ a significant $(\mathrm{p}=.000)$ which depicts that there is association between developed infrastructure of universities and generation of new knowledge as approved by likelihood ratio and linear by linear relationship. Gamma statistic illustrates that there is a significant and positive relation between the variables. Above mentioned analysis presented that poor infrastructure will cause low rate of creation of knowledge economy and rich infrastructure can boost the production of knowledge. In the light of above results the hypothesis "There is association between above said variables is accepted. The same is accepted by Chandra \& Yokoyama (2011) who suggested that Asian countries have to produce knowledge by developing universities.

Hypothesis 3: There is association between funding from universities and production of knowledge.

Table 3.

Association between funding from educational institutions and creation of knowledge economy.

\begin{tabular}{lllllll}
\hline $\begin{array}{l}\text { Funding from } \\
\text { educational } \\
\text { institutions }\end{array}$ & \multicolumn{2}{l}{ Creation of Knowledge economy } & & Total \\
\cline { 2 - 5 } & strongly agree & Agree & $\begin{array}{l}\text { neither agree } \\
\text { nor disagree }\end{array}$ & Disagree & $\begin{array}{l}\text { strongly } \\
\text { disagree }\end{array}$ & \\
Strongly agree & 12 & 5 & 0 & 0 & 0 & 17 \\
& $70.6 \%$ & $29.4 \%$ & $0.0 \%$ & $0.0 \%$ & $0.0 \%$ & $100.0 \%$ \\
Agree & 30 & 84 & 37 & 0 & 0 & 151 \\
Neither agree & 7 & $55.6 \%$ & $24.5 \%$ & $0.0 \%$ & $0.0 \%$ & $100.0 \%$ \\
nor disagree & $3.3 \%$ & 54 & 108 & 42 & 0 & 211 \\
\hline
\end{tabular}




\begin{tabular}{lllllll}
\hline \multirow{2}{*}{ Disagree } & 0 & 1 & 47 & 104 & 15 & 167 \\
& $0.0 \%$ & $0.6 \%$ & $28.1 \%$ & $62.3 \%$ & $9.0 \%$ & $100.0 \%$ \\
Strongly & 0 & 0 & 6 & 41 & 13 & 60 \\
disagree & $0.0 \%$ & $0.0 \%$ & $10.0 \%$ & $68.3 \%$ & $21.7 \%$ & $100.0 \%$ \\
& 49 & 144 & 198 & 187 & 28 & 606 \\
\multirow{2}{*}{ Total } & $8.1 \%$ & $23.8 \%$ & $32.7 \%$ & $30.9 \%$ & $4.6 \%$ & $100.0 \%$ \\
\hline
\end{tabular}

Tests

\begin{tabular}{llll}
\hline & Value & Df & Asymp. Sig. (2-sided) \\
\hline Pearson Chi-Square & $493.513^{\mathrm{a}}$ & 16 & .000 \\
Likelihood Ratio & 521.117 & 16 & .000 \\
Linear-by-Linear Association & 341.816 & 1 & .000 \\
Gamma & .872 & & .000 \\
\hline
\end{tabular}

Table 3 represents the relationship between funding from educational institutions and creation of knowledge economy. Chi-square value $(\chi 2=493.513 \mathrm{a})$, likelihood value, and linear by linear association shows a highly significant $(p=.000)$ relationship between funding and creation of knowledge economy. Gamma statistic proves a highly significant and positive relation between the variables. Analysis give us a picture of opinions of people, lower amount of funding causes lower rate of creation, medium amount of funding causes medium rate of creation, and high amount of funding causes high rate of creation of knowledge economy. Results favor the acceptance of hypothesis "There is association between funding from educational institutions and creation of knowledge economy". Jalil \& Idrees (2013) argued that Pakistan has to invest more in education to achieve higher level of development in knowledge economy.

Hypothesis 4: There is association between provision of incentives by educational institutions and creation of knowledge economy.

Table 4.

Association between provision of incentives by educational institutions and creation of knowledge economy.

\begin{tabular}{lllllll}
\hline \multirow{2}{*}{$\begin{array}{l}\text { Incentives from } \\
\text { educational }\end{array}$} & \multicolumn{2}{l}{ Production of new knowledge } & & \\
\cline { 2 - 5 } Institutions & strongly agree & Agree & $\begin{array}{l}\text { neither agree } \\
\text { nor disagree }\end{array}$ & disagree & $\begin{array}{l}\text { strongly } \\
\text { disagree }\end{array}$ & \\
Strongly agree & 30 & 29 & 1 & 0 & 0 & 60 \\
& $50.0 \%$ & $48.3 \%$ & $1.7 \%$ & $0.0 \%$ & $0.0 \%$ & $100.0 \%$ \\
Agree & 14 & 55 & 19 & 3 & 0 & 91 \\
Neither agree & 5 & $60.4 \%$ & $20.9 \%$ & $3.3 \%$ & $0.0 \%$ & $100.0 \%$ \\
nor disagree & $2.5 \%$ & 54 & 106 & 31 & 4 & 200 \\
Disagree & 0 & $27.0 \%$ & $53.0 \%$ & $15.5 \%$ & $2.0 \%$ & $100.0 \%$ \\
& $0.0 \%$ & 6 & 49 & 77 & 7 & 139 \\
Strongly & 0 & $4.3 \%$ & $35.3 \%$ & $55.4 \%$ & $5.0 \%$ & $100.0 \%$ \\
disagree & $0.0 \%$ & 0 & 23 & 76 & 17 & 116 \\
Total & 49 & $0.0 \%$ & $19.8 \%$ & $65.5 \%$ & $14.7 \%$ & $100.0 \%$ \\
& $8.1 \%$ & 144 & 198 & 187 & 28 & 606 \\
\end{tabular}




\begin{tabular}{llll}
\hline & Value & Df & Asymp. Sig. (2-sided) \\
\hline Pearson Chi-Square & $498.745^{\mathrm{a}}$ & 16 & .000 \\
Likelihood Ratio & 499.029 & 16 & .000 \\
Linear-by-Linear Association & 336.217 & 1 & .000 \\
Gamma & .830 & & .000 \\
\hline
\end{tabular}

Table 4 enables us to understand the relationship between provision of incentives by educational institutions and creation of knowledge economy. Values of Chi-square, likelihood ratio, and linear by linear association represent that there is highly significant relationship between provision of incentives by educational institutions and creation of knowledge economy. Gamma value shows that there is highly significant and a positive relationship exists between above mentioned variables. Results help us to understand the value of incentives in creation of knowledge economy. Lack of incentives discourages creation of knowledge economy on the other hand medium and high numbers of incentives encourage the people to create new knowledge. The hypothesis "There is association between provision of incentives by educational institutions and creation of knowledge economy" in the light of above results. Andria \& Savin (2018) claimed that incentives can be used to motivate people for creation of knowledge economy.

Hypothesis 5. There is association between research and development in educational institutions and creation of knowledge economy.

Table 5.

Association between research and development in educational institutions and creation of knowledge economy.

\begin{tabular}{lllllll}
\hline \multirow{2}{*}{$\begin{array}{l}\text { Research and } \\
\text { development }\end{array}$} & \multicolumn{7}{l}{ Creation of Knowledge economy } & & Total \\
\cline { 2 - 5 } & strongly agree & Agree & $\begin{array}{l}\text { neither agree } \\
\text { nor disagree }\end{array}$ & disagree & $\begin{array}{l}\text { strongly } \\
\text { disagree }\end{array}$ & The \\
Strongly agree & 2 & 1 & 6 & 6 & 2 & 17 \\
& $11.8 \%$ & $5.9 \%$ & $35.3 \%$ & $35.3 \%$ & $11.8 \%$ & $100.0 \%$ \\
Agree & 20 & 64 & 81 & 79 & 9 & 253 \\
Neither agree & 17 & $25.3 \%$ & $32.0 \%$ & $31.2 \%$ & $3.6 \%$ & $100.0 \%$ \\
nor disagree & $7.8 \%$ & 57 & 70 & 62 & 13 & 219 \\
Disagree & 10 & $26.0 \%$ & $32.0 \%$ & $28.3 \%$ & $5.9 \%$ & $100.0 \%$ \\
Strongly & $10.0 \%$ & 18 & 38 & 31 & 3 & 100 \\
disagree & 0 & $18.0 \%$ & $38.0 \%$ & $31.0 \%$ & $3.0 \%$ & $100.0 \%$ \\
Total & $0.0 \%$ & 4 & 3 & 9 & 1 & 17 \\
& 49 & $23.5 \%$ & $17.6 \%$ & $52.9 \%$ & $5.9 \%$ & $100.0 \%$ \\
\hline
\end{tabular}

Test

\begin{tabular}{llll}
\hline & Value & Df & Asymp. Sig. (2-sided) \\
\hline Pearson Chi-Square & $15.917^{\mathrm{a}}$ & 16 & .459 \\
Likelihood Ratio & 17.551 & 16 & .351 \\
Linear-by-Linear & .221 & 1 & .638 \\
Association & .016 & & .751 \\
Gamma & & & \\
\hline
\end{tabular}

Table 5 throws light on the relationship between research and development in educational institutions and creation of knowledge economy. A highly significant and positive relationship is found between research and development and creation of knowledge economy according to the values of Chi-square, likelihood ratio, linear by linear association, and gamma. 


\section{AMAZOND周 \\ 1nvestiga}

The hypothesis "There is association between research and development in educational institutions and creation of knowledge economy" is accepted as approved by the results. The rate of research and development activities positively influence the creation of knowledge economy whereas, the fewer research activities has negative impact on creation of knowledge. World Bank (2010) emphasized that research and development and innovation is not sufficient and

Table 6.

Association between human capital development in educational institutions and creation of knowledge economy.

\begin{tabular}{lllllll}
\hline \multirow{2}{*}{$\begin{array}{l}\text { Human Capital } \\
\text { Development }\end{array}$} & \multicolumn{2}{l}{ Creation of Knowledge economy } & \multicolumn{2}{l}{ neither } \\
\cline { 2 - 4 } & $\begin{array}{l}\text { strongly } \\
\text { agree }\end{array}$ & Agree & $\begin{array}{l}\text { agree nor } \\
\text { disagree }\end{array}$ & disagree & $\begin{array}{l}\text { strongly } \\
\text { disagree }\end{array}$ & Total \\
Strongly agree & 27 & 13 & 0 & 0 & 0 & 40 \\
& $67.5 \%$ & $32.5 \%$ & $0.0 \%$ & $0.0 \%$ & $0.0 \%$ & $100.0 \%$ \\
Agree & 21 & 88 & 37 & 5 & 0 & 151 \\
Neither agree & $13.9 \%$ & $58.3 \%$ & $24.5 \%$ & $3.3 \%$ & $0.0 \%$ & $100.0 \%$ \\
nor disagree & $0.4 \%$ & 42 & 130 & 69 & 5 & 247 \\
Disagree & 0 & $17.0 \%$ & $52.6 \%$ & $27.9 \%$ & $2.0 \%$ & $100.0 \%$ \\
Strongly & $0.0 \%$ & 1 & 31 & 98 & 16 & 146 \\
disagree & 0 & $0.7 \%$ & $21.2 \%$ & $67.1 \%$ & $11.0 \%$ & $100.0 \%$ \\
Total & $0.0 \%$ & 0 & 0 & 15 & 7 & 22 \\
& 49 & $0.0 \%$ & $0.0 \%$ & $68.2 \%$ & $31.8 \%$ & $100.0 \%$ \\
\hline
\end{tabular}

Test

\begin{tabular}{llll}
\hline & Value & Df & Asymp. Sig. (2-sided) \\
\hline Pearson Chi-Square & $574.215^{\text {a }}$ & 16 & .000 \\
Likelihood Ratio & 524.596 & 16 & .000 \\
Linear-by-Linear & 347.438 & 1 & .000 \\
Association & .878 & & .000 \\
Gamma & & & \\
\hline
\end{tabular}

Table 6 explains the relationship between human capital development in educational institutions and creation of knowledge economy. Chi-square value $(\chi 2=574.215 \mathrm{a})$ says that there is a highly significant $(\mathrm{p}=.000)$ relationship, likelihood Ratio (524.596) and linear-by-linear association (347.438) are showing a significant association between the variables. Gamma depicts about a positive and highly significant relationship between the variables. The process of innovation and research requires the supervision of highly qualified and skilled personals. It can be evident by the results that low inappropriate in developing countries for creation of knowledge economy. There is need to pay attention to provide opportunities to establish environment favorable for creation of knowledge economy

Hypothesis 6. There is association between human capital development in educational institutions and creation of knowledge economy. 
Table 7.

Association between collaboration with industry by educational institutions and creation of knowledge economy.

\begin{tabular}{lllllll}
\hline \multirow{2}{*}{$\begin{array}{l}\text { Collaboration } \\
\text { with industry }\end{array}$} & \multicolumn{2}{l}{ Creation of Knowledge economy } & & \\
\cline { 2 - 5 } & strongly agree & Agree & $\begin{array}{l}\text { neither agree } \\
\text { nor disagree }\end{array}$ & disagree & $\begin{array}{l}\text { strongly } \\
\text { disagree }\end{array}$ & Total \\
Strongly agree & 15 & 3 & 0 & 0 & 0 & 18 \\
& $83.3 \%$ & $16.7 \%$ & $0.0 \%$ & $0.0 \%$ & $0.0 \%$ & $100.0 \%$ \\
Agree & 28 & 71 & 13 & 0 & 0 & 112 \\
Neither agree & 6 & $63.4 \%$ & $11.6 \%$ & $0.0 \%$ & $0.0 \%$ & $100.0 \%$ \\
nor disagree & $3.0 \%$ & 66 & 104 & 24 & 0 & 200 \\
Disagree & 0 & $33.0 \%$ & $52.0 \%$ & $12.0 \%$ & $0.0 \%$ & $100.0 \%$ \\
Strongly & $0.0 \%$ & 4 & 78 & 106 & 12 & 200 \\
disagree & 0 & $2.0 \%$ & $39.0 \%$ & $53.0 \%$ & $6.0 \%$ & $100.0 \%$ \\
Total & $0.0 \%$ & 0 & 3 & 57 & 16 & 76 \\
& 49 & $0.0 \%$ & $3.9 \%$ & $75.0 \%$ & $21.1 \%$ & $100.0 \%$ \\
\hline
\end{tabular}

Tests

\begin{tabular}{llll}
\hline & Value & Df & Asymp. Sig. (2-sided) \\
\hline Pearson Chi-Square & $602.917^{\mathrm{a}}$ & 16 & .000 \\
Likelihood Ratio & 592.107 & 16 & .000 \\
Linear-by-Linear Association & 377.103 & 1 & .000 \\
Gamma & .906 & & .000 \\
\hline
\end{tabular}

Table 7 illustrates the relationship between collaboration with industry and creation of knowledge economy. Chi-square value $(\chi 2=602.917 \mathrm{a})$ a highly significant $(\mathrm{p}=.000)$ which depicts association between collaboration with industry and creation of knowledge economy. Further statistical tests i.e. likelihood ratio (592.107) and linear-by-linear association (377.103) also are showing a highly significant association between the variables. Higher levels of linkages between industries and universities are fruitful for both for creation of new knowledge through research and innovation. Medium level of relationship between them has an average impact of creation of knowledge economy and low level of collaboration results slow rate of creation of knowledge as results guide us. Weber (2011) pointed out that the countries in which educational intuitions will not able to develop linkages with industry to grow knowledge economy will be marginalized.

Table 8.

Pearson Correlation Coefficient Values showing relationship between independent variables (and intervening) and dependent variables(creation of knowledge economy) variables.

\begin{tabular}{ll}
\hline Variables & Pearson Correlation Coefficient Value \\
\hline Access to knowledge & .056 \\
Rich infrastructure & .787 \\
Funding & .752 \\
Incentives & .745 \\
Research and development & .019 \\
Human Capital development & .758 \\
Collaboration with industry & .790 \\
\hline
\end{tabular}

Various statistical techniques were applied to measure the results. The purpose of applying these methods was to examine the association or relationship between depend and independent variables. Correlation coefficient test predicts about the correlation between understudy variables. The value of correlation coefficients for independent variables such as access to 


\section{AMAZONUA \\ 1nvestiga}

knowledge, rich infrastructure, funding, incentives, research and development, human capital development, and collaboration with industry are associated with the dependent variable (creation of knowledge economy).

\section{Multi-variate Analysis Linear Regression Analysis}

The regression coefficient shows the rate of change of response variables when predictor variable is changed for one unit.

Table 9.

Result of multivariate analysis: regression coefficient and level of significance of predictor variables.

\begin{tabular}{lllll}
\hline \multicolumn{3}{l}{ Model Summary } & & \\
\hline Mode & $\mathrm{R}$ & R Square & Adjusted R Square & Std. Error of the Estimate \\
1 & $.908^{\mathrm{a}}$ & .824 & .822 & 2.08969 \\
1 & & &
\end{tabular}

a. Predictors: (Constant), Access to Knowledge, Rich Infrastructure, Funds, Incentives, Research and Development, Human Capital Development, Collaboration with industry

ANOVA $^{\mathrm{a}}$

\begin{tabular}{|c|c|c|c|c|c|c|}
\hline Model & & $\begin{array}{l}\text { Sum of } \\
\text { Squares }\end{array}$ & Df & Mean Square & $\mathrm{F}$ & Sig. \\
\hline \multirow{3}{*}{1} & Regression & 12233.526 & 7 & 1747.647 & 400.213 & $.000^{\mathrm{b}}$ \\
\hline & Residual & 2611.341 & 598 & 4.367 & & \\
\hline & Total & 14844.866 & 605 & & & \\
\hline
\end{tabular}

a. Dependent Variable: Creation of Knowledge economy

b. Predictors: (Constant), Access to Knowledge, Rich Infrastructure, Funds, Incentives, Research and Development, Human Capital Development, Collaboration with industry

The value of R-Square in the model summary is 0.641 . This shows that the $64 \%$ change in creation of knowledge economy was explained by the seven variables such as access to knowledge, rich infrastructure, funds, incentives, research and development, human capital development, and collaboration with industry in the model.
The overall model is statistically significant according to the findings of the research results. To judge the significance of the model F-test was applied. The F-value is 400.213, which is significant at less than one \% level of significant. The value obtained suggests that the model is highly significant. The impact of each individual variable is prescribed as:

\begin{tabular}{|c|c|c|c|c|c|c|}
\hline \multicolumn{7}{|c|}{ Coefficients } \\
\hline \multirow{3}{*}{ Mod } & & Unsta & & Standardized & \multirow{3}{*}{$\mathrm{T}$} & \multirow{3}{*}{ Sig. } \\
\hline & & \multicolumn{2}{|c|}{ Coefficients } & \multirow{2}{*}{$\begin{array}{l}\text { Coefficients } \\
\text { Beta }\end{array}$} & & \\
\hline & & B & Std. Error & & & \\
\hline \multirow{8}{*}{1} & (Constant) & .738 & .572 & & 1.291 & 197 \\
\hline & $\begin{array}{l}\text { Access to } \\
\text { Knowledge }\end{array}$ & -.003 & .028 & -.003 & -.107 & .915 \\
\hline & $\begin{array}{l}\text { Rich } \\
\text { Infrastructure }\end{array}$ & .219 & .037 & .225 & 5.870 & .000 \\
\hline & Funds & .225 & .044 & .173 & 5.076 & .000 \\
\hline & Incentives & .301 & .066 & 143 & 4.528 & .000 \\
\hline & $\begin{array}{l}\text { Research and } \\
\text { Development }\end{array}$ & .028 & .033 & .023 & .831 & .406 \\
\hline & $\begin{array}{l}\text { Human Capital } \\
\text { Development }\end{array}$ & .221 & .046 & .162 & 4.787 & .000 \\
\hline & $\begin{array}{l}\text { Collaboration } \\
\text { with industry }\end{array}$ & 286 & .036 & .287 & 7.837 & .000 \\
\hline
\end{tabular}




\section{Access to knowledge}

The beta value (-.003) is indicating a negative but significant relation between access to knowledge and creation of Knowledge economy. It shows that if the educational institutions will provide more access to knowledge that will increase creation of knowledge economy as Cook \& Brown (1999) claimed that gaining knowledge is significant for one to grow and Lundvall and Johnson, (1994) said one can be strong economically if one is knowledgeful.

\section{Rich Infrastructure}

The beta value $(0.219)$ is indicating a positive and significant relation between rich infrastructure and creation of Knowledge economy. It shows that infrastructure of the institutions has relationship with creation of knowledge economy. Peters (2003) emphasized that technological changes are required for economic growth and without rich infrastructure it could not possible.

\section{Funds}

The beta value (.225) indicating a positive and significant relationship between provision of funds and creation of knowledge economy. If the educational institutions invest more it will increase the creation of knowledge economy. Mian, et, al.(2010) suggested that if any country wants to develop it economically, it has to find funding agencies like industry.

\section{Incentives}

The beta value (.301) is predicting a positive and significant relationship between incentives and creation of knowledge economy. Incentives can increase the production of knowledge economy. As Barosso (2005) proposed that universities have to motivate researchers by giving them opportunities like awards and payments (incentives) to expand its role in science and technology, and innovation for creation of knowledge.

\section{Research and Development}

The beta value (.028) is representing a positive and significant relationship between research and development and creation of knowledge economy. It shows that better environment for research and development can increase creation of knowledge economy. According to European Commission (2005) that in global economy, research and development, knowledge, innovation and education, are key components of creation of new knowledge.

\section{Human Capital Development}

The beta value (.221) indicating a positive and significant relationship between human capital development and creation of knowledge economy. Human capital development has direct and positive impact on creation of knowledge economy. The same is presented by Chandra \& Yokoyama (2011) argued that Asian countries have to develop institutional infrastructure and human capital to produce knowledge economy.

\section{Collaboration with industry}

The beta value (.221) is presenting a positive and significant relation between collaboration with industry and creation of knowledge economy. It shows that collaboration with industry can increase the creation of knowledge economy. Collaboration between industry and educational institutions is critical component for efficient national innovation system and production of knowledge (World Bank, 2013).

\section{Conclusion}

It is concluded that independent variables access to knowledge, funds and incentives, and research and development have more significant relation with creation of knowledge economy as compare with other independent variables such as rich infrastructure, human capital development, and collaboration with industry. Lundvall and Johnson, (1994) highlighted the importance of knowledge for production of knowledge, Mian, et, al.(2010) suggested that funding should be raised by any mean for creation of knowledge, Barosso, (2005) proposed that incentives should be used as tools to motivate researchers, and it is declared by European Commission (2005) collaboration with industry is the only way to compete with the global economy.

\section{Recommendations for Further Studies}

The future of Pakistan's economy wholly depends on the rate of production of new knowledge. So, there is need for further studies which can help policy makers to find the directions to develop Pakistan economically.

- How to integrate all the institutions to support creation of knowledge economy?

- What kind of knowledge can develop Pakistan economically? 


\section{AMAZOND凨}

- Why there is gap between educational institutions and industry and how this gap can be reduced and how we can develop human capital with limited resources?

\section{Reference}

Amjad, R. (2006). Why Pakistan must break-into the knowledge economy. MPRA Paper 34448, Germany: University Library of Munich.

Ankrah, S., \& Omar, A. T. (2015). Universitiesindustry collaboration: A systematic review. Scandinavian Journal of Management, 31(3), 387-408.

Andria, D \& Ivan Savin. (2018). A Win-WinWin? Motivating innovation in a Knowledge economywith tax incentives. Technological Forecasting and Social Change, vol. 127, issue C, 38-56.

Barosso, J. M. (2005). Strong Universities for Europe. Speech given to the European Universities Association Convention, Glasgow. British Council. (2012). The shape of things to come: Higher education global trends and emerging opportunities to 2020. Global edition. Chen, D. H., \& Dahlman, C. J. (2005). The knowledge economy, the KAM methodology and World Bank operations. World Bank Institute Working Paper, (37256).

Chandra, D. S., \& Yokoyama, K. (2011). "The role of good governance in the knowledge-based economic growth of East Asia - A study on Japan, Newly Industrialized Economies, Malaysia and China". Graduate School of Economics, Kyushu University.

Cook, S. D., \& Brown, J. S. (1999). Bridging epistemologies: The generative dance between organizational knowledge and organizational knowing. Organization Science, 10(4), 381-400. Conceição, P., \& Heitor, M.V. (1999). On the role of the university in the knowledge economy. Science and Public Policy, vol 26 (1), pp 37-51 European Commission. (2005). Mobilising the Brainpower of Europe: Enabling Universities to Make their Full Contribution to the Lisbon Strategy. European Higher Education in a Worldwide Perspective. Commission Staff Working Paper - Annex to the Communication from the Commission [SEC(2005)518].

Forstorp, P. A., \& Mellström, U. (2013). Eduscapes: Interpreting transnational flows of higher education. Globalisation, Societies and Education, 11(3), 335-358.

Guile, D. (2001). Education and The Economy: Rethinking The Question Of Learning For The 'Knowledge. Era. Futures, 33, 469-482.

Hicks, D. (2012). Performance-based university research funding systems. Research policy, 41(2), 251-261.
Ioana, M. I., Anda, M. I., Ioan, P., \& Bianca, R. A. (2015). The importance of community involvement in research and innovation between 2014-2020. Procedia-Social and Behavioral Sciences, 182, 619-622.

Jalil, A. \& Idrees, M. (2013). Modeling the impact of education on the economic growth: Evidence from aggregated and disaggregated time series data of Pakistan. Economic Modelling, Elsevier, vol. 31@, p. 383-388.

Mushtaq, M. (2020). Role of Institutional Theory and Quality Prevalence in Higher Educational Institution. Revista Amazonia Investiga, 9(30), 10-23.

https://amazoniainvestiga.info/index.php/amazo nia/article/view/1433

Mushtaq, M., Ch, A., Parveen, S., Hussain, S., \& Iqbal, S. (2020). Leadership Characteristics and Quality Prevalence in Higher Education. Revista Amazonia Investiga, 9(31), 82-95. https://amazoniainvestiga.info/index.php/amazo nia/article/view/1456

Kefela, G. T. (2010). Knowledge-based economy and society has become a vital commodity to countries. International NGO Journal, 5(7), 160-166.

Levy, C., \& Hopkins, L. (2010). Shaping up for innovation: are we delivering the right skills for the 2020 knowledge economy?. London: The Work Foundation.

Lundvall, A. B., \& Johnson, B. (1994). The Learning Economy. Journal of Industry Studies, $1: 2,23-42$.

Mathew, A. O., \& Rodrigues, L. L. (2015). Effect of incentives on knowledge sharing and learning-Evidence from the Indian IT sector. International Journal of Social, Behavioral, Educational, Economic and Management Engineering, 9(3), 763-768.

McGregor, J., Tweed, D., \& Pech, R. (2004). Human capital in the new economy: devil's bargain?. Journal of Intellectual Capital. Vol 5 (1), pp. 153-164.

Mian, et, al. (2010). Building Knowledge Regions in Developing Nations With Emerging Innovation Infrastructure: Evidence From Mexico And Pakistan. Int. J. Innovation and Regional Development, Vol. 2 (4).

Peters, A. M. (2003). Classical Political Economy and The Role Of Universities In The New Knowledge Economy. Globalization, Societies and Education, 1:2, 153-168.

Robertson, S. L. (2005). Re-imagining and rescripting the future of education: Global knowledge economy discourses and the challenge to education systems. Comparative education, 41(2), 151-170.

Soriano, F. H., \& Mulatero, F. (2010). Knowledge policy in the EU: From the Lisbon 
strategy to Europe 2020. Journal of the Knowledge Economy, 1(4), 289-302.

Tarar, N. O. (2006). Globalisation and higher education in Pakistan. Economic and Political Weekly, 41(49), pp. 5080-5085.

Weber, S. A. (2011). The role of education in knowledge economies in developing countries. Procedia Social and Behavioral Sciences, Vol 15, pp 2589-2594.
World Bank. (2013). World Development Report. Washington, DC: World Bank.

World Bank Institute. (2010). Measuring Knowledge In The World's Economies: Knowledge Assessment Methodology And Knowledge Economy Index. Washington: Knowledge for Development (K4D) Program. 